\title{
ORGANIZACJE PARTNERSKIE NA JEDNYM OBSZARZE TURYSTYCZNYM - PROBLEMY I WYZWANIA
}

\section{WSTEPP}

Obecnie postrzega się współpracę wewnątrz- i międzysektorową ${ }^{1}$ (w sektorze publicznym, prywatnym i między ich reprezentantami) jako narzędzie osiaggania przewagi konkurencyjnej przez podmioty indywidualne oraz obszary turystyczne $^{2}$. Kooperację taką można rozumieć jako formę dobrowolnego współdziałania, w którym autonomiczni interesariusze angażują się w interaktywny proces, wykorzystując wspólne reguły, normy i struktury, by działać lub decydować $\mathrm{w}$ sprawach związanych $\mathrm{z}$ rozwojem turystyki na danym obszarze $^{3}$. Kooperacja może przykładowo dotyczyć wspólnego programowania rozwoju (w tym opracowywania dokumentów strategicznych), inwestycji infrastrukturalnych, czy wspólnych działań marketingowych (głównie w zakresie promocji, np. udział w targach, wspólne finansowanie materiałów promocyjnych, tworzenie systemu identyfikacji wizualnej itp.).

Ze względu na złożony charakter regionalnego produktu turystycznego, na który składa się pakiet składników materialnych i niematerialnych dostępnych w miejscu docelowym ${ }^{4}$, współpraca podmiotów odpowiedzialnych za elementy składowe tego produktu jest nieodzowna. Turysta postrzega bowiem swój pobyt $\mathrm{w}$ danym miejscu przez satysfakcję z wiązki różnego rodzaju dóbr i usług, które konsumuje i z których korzysta, a za które częściowo odpowiedzialny jest sektor publiczny (np. drogi, infrastruktura sanitarna) i sektor prywatny (obiekty noclegowe, gastronomiczne, atrakcje turystyczne itp.). Kooperacja pozwala ponadto osiągnąć szereg korzyści - przez efekt synergii partnerzy mogą działać skuteczniej i sprawniej. Jest to możliwe dzięki łączeniu komplementarnych zasobów różnych podmiotów.

Potencjalne korzyści współpracy stymulują powstawanie w różnych krajach świata, w tym w Polsce, kolejnych organizacji partnerskich. Ich liczba w Polsce zaczęła gwałtownie rosnąć, w szczególności po powołaniu Polskiej Organizacji

\footnotetext{
${ }^{1}$ Podziału sektorów dokonano na podstawie kryterium formy własności i celu działalności. J. Beksiak, Państwo w polskiej gospodarce lat dziewięćdziesiatych XX wieku, WN PWN, Warszawa 2001.

2 J. C. Crotts, D. Buhalis, R. March, Global Alliances in Tourism and Hospitality Management, The Haworth Hospitality Press, An Imprint of The Haworth Press, Inc., New York-London-Oxford 2000; A. Fyall, B. Garrod, Tourism Marketing. A Collaborative Approach, Channel View Publications, Clevedon 2005.

${ }^{3}$ D. J. Wood, B. Gray, Toward a Comprehensive Theory of Collaboration, „Journal of Applied Behavioral Science" 27, 1991, nr 2, s. 146.

${ }^{4}$ V. T. C. Middleton, Marketing $w$ turystyce, Polska Agencja Promocji Turystyki, Warszawa 1996, s. 95 .
} 
Turystycznej (przełom XX i XXI w.) ${ }^{5}$, a wraz z nią lokalnych i regionalnych organizacji turystycznych. Nie bez znaczenia był także dostęp do środków unijnych, nierzadko pozyskiwanych dzięki kooperacji z innymi partnerami. Wśród obecnie funkcjonujących struktur wymienić można liczne formy współpracy wewnątrz- i międzysektorowej. Stanowią je: związki/porozumienia międzygminne, euroregiony, wspomniane już lokalne/regionalne organizacje turystyczne (LOT i ROT), lokalne grupy działania (LGD) i inne (np. izby gospodarcze, lokalne organizacje w formie stowarzyszeń, fundacji itp.). Najogólniej celem tych struktur jest nawiązanie współpracy, mającej w bezpośredni lub pośredni sposób służyć rozwojowi turystyki na danym obszarze. Organizacje te różnią się jednak między sobą np. celem działalności, prawnymi możliwościami funkcjonowania czy rodzajem partnerów, jakich moga zrzeszać, itp. Ich charakterystyki dokonano w tabeli 1 .

\section{Tabela 1}

Charakterystyka wybranych rodzajów struktur partnerskich działających na rzecz rozwoju turystyki

\begin{tabular}{|l|l|}
\hline \multicolumn{1}{|c|}{ Rodzaj struktury } & \multicolumn{1}{c|}{ Charakterystyka } \\
\hline LGD $^{6}$ & $\begin{array}{l}\text { Powstają na obszarach wiejskich w ramach unijnego programu } \\
\text { Leader. Realizują zadania służące rozwojowi społeczno-gospo- } \\
\text { darczemu tych obszarów, w tym m.in. turystyki. Zrzeszaja } \\
\text { podmioty sektora publicznego, prywatnego i non-profit. Zgodnie } \\
\text { z wymogami programu działania LGD powinny być innowa- } \\
\text { cyjne, tzn. przynosić nowe rozwiąania problemów obszarów } \\
\text { wiejskich albo wiazać się z powstaniem nowego produktu, } \\
\text { procesu czy formy organizacyjnej. }\end{array}$ \\
\hline LOT i ROT $^{7}$ & $\begin{array}{l}\text { Powoływane sá przede wszystkim w celu promocji turystycznej } \\
\text { obszarów zarówno wiejskich, jak i miejskich). ROT zrzeszają } \\
\text { jednostki samorządu terytorialnego wszystkich szczebli, ze } \\
\text { szczególnym uwzględnieniem samorządów województw, LOT } \\
\text { zaś - gminy i powiaty. Zarówno jedne, jak i drugie, poza } \\
\text { samorządami, zrzeszają organizacje gospodarcze i zawodowe } \\
\text { branży turystycznej, a także pojedyncze podmioty, głównie } \\
\text { przedsiębiorstwa turystyczne zainteresowane rozwojem tury- } \\
\text { styki na danym terenie. Ich celem jest przede wszystkim } \\
\text { promocja turystyczna obszarów, na terenie których funkcjo- } \\
\text { nuja. }\end{array}$ \\
\hline
\end{tabular}

${ }^{5}$ Powołano ją na mocy ustawy z 25 czerwca 1999 r. o Polskiej Organizacji Turystycznej, Dz. U. 1999, Nr 62, poz. 689 ze zm.

${ }^{6}$ Ich tworzenie i funkcjonowanie odbywa się w szczególności na podstawie następujących aktów prawnych: ustawa z 7 marca 2007 r. o wspieraniu rozwoju obszarów wiejskich z udziałem środków Europejskiego Funduszu Rolnego na rzecz Rozwoju Obszarów Wiejskich, Dz. U. Nr 64, poz. 427 oraz 2008, Nr 98, poz. 634; Dz. Urz. UE L 277/1 rozporządzenie Rady (WE) nr 1698/2005 z 20 września 2005 r. w sprawie wsparcia rozwoju obszarów wiejskich przez Europejski Fundusz Rolny na rzecz Rozwoju Obszarów Wiejskich (EFRROW).

7 Powołano je na postawie ustawy z 25 czerwca 1999 r., op. cit. 
cd. tab. 1

\begin{tabular}{|l|l|}
\hline $\begin{array}{l}\text { Związki } \\
\text { i porozumienia } \\
\text { międzygminne }\end{array}$ & $\begin{array}{l}\text { Związki i porozumienia międzygminne służa rozwojowi spo- } \\
\text { łeczno-gospodarczemu (w tym turystycznemu) gmin, które do } \\
\text { nich należą (ich członkami moga być jedynie samorządy } \\
\text { terytorialne). W wypadku związku międzygminnego powstaje } \\
\text { nowy podmiot prawny, który przejmuje na siebie część zadań } \\
\text { gminnych, w wypadku porozumienia zaś jedna z gmin bierze na } \\
\text { siebie wybrane zadania i realizuje je (ze wspólnych środków) } \\
\text { w imieniu pozostałych. Istotą funkcjonowania związków i po- } \\
\text { rozumień międzygminnych jest realizacja zadań wykracza- } \\
\text { jących poza możliwości jednej gminy (np. finansowanie infra- } \\
\text { struktury niezbędnej do rozwoju turystyki). }\end{array}$ \\
\hline Euroregiony $^{9}$ & $\begin{array}{l}\text { Są to struktury współpracy transgranicznej między sasia- } \\
\text { dującymi ze sobą władzami jednostek lokalnych i regionalnych } \\
\text { usytuowanych wzdłuż wspólnych granic państwowych. Współ- } \\
\text { praca euroregionalna służy krzewieniu wzajemnego zrozu- } \\
\text { mienia, budowaniu stosunków kulturalnych i wzmocnieniu } \\
\text { współpracy gospodarczej, m.in. przez rozwój turystyki }{ }^{10} .\end{array}$ \\
\hline
\end{tabular}

Źródło: opracowanie własne.

Praktyka pokazuje jednak, że wiele $\mathrm{z}$ przedstawionych struktur jest niestabilnych. W szczególności gdy kończą się fundusze przeznaczone na finansowanie ich działalności (np. unijne), często kończy się także sama współpraca $^{11}$. Obserwuje się również powstawanie wielu nowych organizacji partnerskich, których cele i zadania nie sa skoordynowane z celami i zadaniami organizacji już istniejących na danym obszarze. Pojawia się wówczas ryzyko powielania tych samych wysiłków, co z ekonomicznego punktu widzenia czyni podejmowane działania nieefektywnymi. Celem artykułu jest identyfikacja i charakterystyka problemów związanych z funkcjonowaniem na danym obszarze różnych organizacji partnerskich działających na rzecz rozwoju turystyki. Autorka podejmie także próbę wskazania przyczyn zidentyfikowanych problemów.

${ }^{8}$ Tworzone są na podstawie art. 64-73a ustawy z 8 marca 1990 r. o samorządzie gminnym, Dz. U. 2001, Nr 142, poz. 1591.

${ }^{9}$ Działalność transgraniczną i euroregionalną regulują konwencje odpowiednich struktur międzynarodowych - Rady Europy i UE: Europejska konwencja ramowa o współpracy transgranicznej między Wspólnotami i Władzami Terytorialnymi (tzw. Konwencja madrycka z 21 maja 1980 r.), Europejska karta samorządu lokalnego, Europejska karta samorządu regionalnego, Europejska karta regionów granicznych i transgranicznych.

${ }^{10}$ Więcej na temat różnych form współpracy w turystyce por. szerzej: K. Czernek, Uwarunkowania wspótpracy na rzecz rozwoju turystyki w regionie, Proksenia, Kraków, s. 36-46.

${ }^{11}$ Przykładowo, aż 75\% organizacji partnerskich objętych badaniem w województwie pomorskim, powstałych w ramach dwóch projektów: „Turystyka - Wspólna Sprawa” i „Program Produktów Turystycznych" przestało funkcjonować w momencie wyczerpania źródła finansowania (formalne zakończenie projektu). Por. J. Zdrojewski, Wybrane narzędzia wspierania partnerstwa $w$ rozwoju produktów turystycznych na przyktadzie województwa pomorskiego, Uniwersytet Gdański, Gdańsk 2007. 


\section{PRZEGLĄD LITERATURY}

Problematyka funkcjonowania na jednym obszarze turystycznym wielu różnych organizacji partnerskich jest podejmowana w literaturze dotyczącej kooperacji w turystyce, zakres tych rozważań jest jednak stosunkowo ograniczony. Często problemy związane z żywiołowym (szybkim i spontanicznym) powstawaniem struktur partnerskich poruszane sa niejako mimochodem, przy omawianiu wielu innych aspektów kooperacji. Dotyczy to zarówno literatury zagranicznej, jak i polskiej.

Wielu zagranicznych autorów uznaje, że podstawowym problemem związanym z wielością i różnorodnością struktur funkcjonujących na danym terenie jest brak skoordynowania działań między nimi - prowadzi to do powielania wysiłków, marnotrawienia zasobów, a nawet do nieuzasadnionej konkurencji czy konfliktu między organizacjami ${ }^{12}$. J. Briedenhann i E. Wickens twierdzą, że wynika to głównie z braku jasnego podziału ról - zwłaszcza między sektorami publicznym i prywatnym, dążenia ich reprezentantów głównie do własnych celów, bez uwzględnienia interesów pozostałych podmiotów oraz z braku wiedzy, jak rozwijać współpracę w różnych jej formach ${ }^{13}$.

Na podobne przyczyny wskazuje w swoich badaniach D. Dredge. Autorka zidentyfikowała wiele problemów związanych z rozwojem współpracy w jednym z australijskich regionów. Jednym z nich był brak akceptacji powstania lokalnej organizacji turystycznej przez radę miasta. Jej członkowie obawiali się bowiem, że funkcjonowanie LOT przysporzy urzędnikom dodatkowej pracy. Ponadto, działania rady i LOT zaczęły być postrzegane przez obie strony jako konkurencyjne, czego przejawem było powołanie przez urzędników nowej organizacji, powstałej z całkowitym pominięciem przedsiębiorców. Gdy z czasem udało się powołać LOT, była ona całkowicie kontrolowana przez radę, co spotkało się ze sprzeciwem sektora prywatnego i zaostrzyło konflikt między obu sektorami. D. Dredge wskazała, iż powodem zidentyfikowanych problemów były m.in. brak wiedzy władz lokalnych, jak rozwijać współpracę, i wynikający stąd niejasny podział ról, a także brak lokalnego lidera ${ }^{14}$.

Na podobne problemy i ich przyczyny wskazuje się w literaturze polskiej. Twierdzi się m.in., że jedną z ważniejszych barier kooperacji w turystyce jest brak określenia podziału kompetencji na obszarach turystycznych. Nie wiadomo, jakie

\footnotetext{
12 J. Briedenhann, E. Wickens, Tourism Routes as a Tool for the Economic Development of Rural Areas - Vibrant Hope or Impossible Dream?, „,Tourism Management” 25, 2004, nr 1, s. 71-79; A. Ladkin, A. M. Bertramini, Collaborative Tourism Planning: A Case Study of Cusco, Peru, „Current Issues in Tourism" 5, 2002, nr 2, s. 71-93; M. G. Reed, Power Relations and Community-Based Tourism Planning, „Annals of Tourism Research” 21, 1997, nr 3, s. 566-591; A. Yuksel, F. Yuksel, Managing Relations in a Learning Model for Bringing Destinations in Need of Assistance into Contact with Good Practice, „Tourism Management” 26, 2005, s. 667-679.

13 J. Briedenhann, E. Wickens, op. cit.

${ }^{14}$ D. Dredge, Policy Networks and the Local Organisation of Tourism, ,Tourism Management” 27, 2006, nr 2, s. 269-280.
} 
powinny być relacje między ROT a wydziałem turystyki urzędu marszałkowskiego oraz odpowiednio LOT a wydziałem zajmującym się turystyką w gminie - tzn. co ma pozostawać w gestii urzędu, a co przekazać do LOT czy ROT $^{15}$. Także autorzy badań obejmujących 80 różnych struktur partnerskich $\mathrm{w}$ turystyce $\mathrm{w}$ województwie pomorskim stwierdzili, że podmiotami utrudniającymi są czasami (np. w wypadku LOT) władze samorządowe, które nie chca wspierać partnerstwa lub współdziałać z obawy przed utratą wpływu na rozwój turystyki lub przekazywanie środków $\mathrm{w}$ - ich zdaniem - obce ręce ${ }^{16}$.

Z kolei do grupy najważniejszych barier wdrażania programu Leader w Polsce zaliczono: niechęć administracji centralnej i lokalnej do oddania części kompetencji i kontroli lokalnym społecznościom, brak tradycji równoprawnej współpracy trójsektorowej, faworyzowanie sektora publicznego, traktowanie jako bardziej priorytetowych decyzji przynoszących szybkie i doraźne efekty oraz brak chęci i umiejętności długofalowego i perspektywicznego myślenia ${ }^{17}$.

Jak wspomniano, problemom związanym z żywiołowym powstawaniem struktur partnerskich nie poświęca się w literaturze osobnego miejsca, mimo że ich efekt dla lokalnych gospodarek może być znaczący z ekonomicznego punktu widzenia, zatem zagadnienie to wymaga zgłębienia. Umożliwi to lepsze wyjaśnienie jego przyczyn, i ewentualnych sposobów przeciwdziałania negatywnym rezultatom z nim związanym.

W tym celu wykorzystano analizę organizacji partnerskich działających na obszarze pięciu beskidzkich gmin: Szczyrku, Wisły, Ustronia, Brennej i Istebnej, które tworza porozumienie międzygminne o nazwie „Beskidzka 5”. Opis wyników badań poprzedzono krótką charakterystyką tego obszaru oraz przedstawieniem metodologii badań.

\section{METODOLOGIA}

Aby osiagnąć cel artykułu, wykorzystano eksploracyjne badania o charakterze jakościowym ${ }^{18}$. Badania eksploracyjne stosowane sa, gdy problematyka objęta badaniem nie jest dobrze znana. W związku z tym ich celem nie

${ }^{15}$ M. Migdal, Ewaluacja Regionalnych i Lokalnych Organizacji Turystycznych, Forum Turystyki Regionów, Szczecin 2008.

${ }^{16}$ J. Zdrojewski, Charakterystyka wybranych przypadków produktów turystycznych realizowanych $w$ formule partnerskiej $w$ województwie pomorskim $i$ wskazanie praktycznych wniosków z analizy, materiał niepublikowany, opracowany w ramach projektu AGORA - Network Sustainable Tourism Development in the Baltic Sea Region, Projekt Inicjatyw Wspólnoty Interreg IIIB z udziałem pracowników Katedry Makroekonomii Uniwersytetu Gdańskiego, Gdańsk 2006, s. 11.

17 J. Głuszyński, Inicjatywa Lider w Polsce, Prezentacja wyników badań na temat funkcjonowania Lokalnych Grup Działania w Polsce (Projekt badawczy na temat inicjatywy Leader + przeprowadzony na zlecenie Urzędu Komitetu Integracji Europejskiej; okres objęty badaniem - listopad 2004 - styczeń 2005).

${ }^{18}$ Służyły one osiągnięciu szerszego celu niż ten postawiony w artykule. Mianowicie, było nim zidentyfikowanie różnego rodzaju uwarunkowań kooperacji wewnątrz- i międzysektorowej w regionie turystycznym. Wśród wielu uwarunkowań zidentyfikowano także problemy wynikające z funkcjonowania na jednym obszarze wielu różnych struktur partnerskich. Jednak nie zostały one szerzej opisane w publikacji podsumowującej wyniki badań (K. Czernek, op. cit.). W związku z tym zdecydowano się w tym miejscu pogłębić tę problematykę. 
jest weryfikacja hipotez, lecz raczej rozwiązanie postawionego problemu badawczego i większe rozeznanie się w słabo poznanej materii.

Zgodnie ze specyfika badań eksploracyjnych, wybierając obszar badań, zastosowano celowy dobór próby przy wykorzystaniu metodologii poszerzonego zbiorowego studium przypadku (grupa kilku gmin) ${ }^{19}$. Obszar wybrany do badań musiał spełniać następujące kryteria doboru próby:

- próba miała umożliwić zweryfikowanie koncepcji będących efektem przeglądu literatury,

- badane zjawiska (duża liczba organizacji partnerskich) musiały być obecne w dobranej próbie,

- musiała istnieć możliwość dokonania tzw. generalizacji analitycznej, której celem jest wysunięcie generalnych konkluzji przez wskazanie pewnych wzorów, praw czy teorii, umożliwiających wyjaśnienie zjawiska lub użytecznych do jego dalszego zgłębienia (nie jest to jednak generalizacja statystyczna na podstawie reprezentatywności próby),

- dobór próby miał umożliwić dokonanie wiarygodnych opisów i wyjaśnień na temat badanych zjawisk w ich naturalnym otoczeniu,

- posiadane zasoby musiały być wystarczające, by móc przeprowadzić badania $^{20}$.

W efekcie do badań wybrano obszar pięciu beskidzkich gmin - Szczyrku, Wisły, Ustronia (gminy miejskie) oraz Brennej i Istebnej (gminy wiejskie). Wszystkie gminy należą do Beskidu Śląskiego, pod względem administracyjnym stanowią część województwa śląskiego. Poza Szczyrkiem (będącym częścią powiatu bielskiego) wszystkie pozostałe należą do powiatu cieszyńskiego. Obszar charakteryzuje się wysokim potencjałem turystycznym. Składaja się nań zarówno unikatowe naturalne walory krajobrazu górskiego, jak i liczne antropogeniczne atrakcje turystyczne i kulturowe oraz obiekty zagospodarowania turystycznego.

Od $2004 \mathrm{r}$. pięć wymienionych gmin tworzy porozumienie międzygminne o nazwie „Beskidzka 5”. Jego celem jest rozwój i promocja turystyki na wspólnym obszarze turystycznym. Na terenie „Beskidzkiej 5” w okresie prowadzonych badań rozwijało się także wiele innych form współpracy, zarówno wewnątrz-, jak i międzysektorowej - ich krótkiego omówienia dokonano w dalszej części rozważań.

Badania trwały od lipca 2008 do października 2010 r. Dobór rozmówców do badań był celowy, połączony z techniką kuli śnieżnej. Chodzi w niej o zebranie informacji od kilku członków badanej populacji, których da się odszukać, i których następnie prosi się o dostarczenie informacji potrzebnych do doboru do badań kolejnych rozmówców ${ }^{21}$. Rozmówcami byli:

19 D. Silverman, Prowadzenie badań jakościowych, WN PWN, Warszawa 2008, s. 172.

${ }^{20}$ M. B. Miles, A. M. Huberman, Analiza danych jakościowych, Trans Humana, Białystok 2000, s. 18.

${ }^{21}$ R. Stake, Jakościowe studium przypadku, w: N. K. Denzin, Y. S. Lincoln (red.), Metody badań jakościowych, WN PWN, Warszawa 2009, s. 213; E. Babbie, Podstawy badań społecznych, WN PWN, Warszawa 2008, s. 334. 
- przedstawiciele sektora publicznego (wójtowie/burmistrzowie poszczególnych gmin oraz urzędnicy odpowiedzialni w tych gminach za turystykę),

- przedstawiciele sektora prywatnego (reprezentanci obiektów noclegowych, gastronomicznych, atrakcji turystycznych, punktów sprzedaży pamiątek, biur pośrednictwa w organizowaniu turystyki na miejscu),

- podmioty uznane przez dotychczasowych rozmówców za wartościowe źródło informacji w zakresie różnego rodzaju form kooperacji wewnątrzi międzysektorowej na obszarze „Beskidzkiej 5”.

W odniesieniu do rozmówców zastosowano metodę wywiadu swobodnego pogłębionego (tzw. eksploracyjnego). Miało to zapewnić im swobodę wypowiedzi niezbędna $\mathrm{w}$ tego typu badaniach. Dla pogłębienia i zweryfikowania wiedzy uzyskanej na podstawie wywiadów zastosowano także obserwację (udział badacza w zebraniach dwóch organizacji partnerskich) oraz analizę dokumentów. Wykorzystano dokumenty planistyczne jednostek samorządowych, dokumenty struktur partnerskich (strategie/programy działań, raporty, sprawozdania, statuty itp.), akty prawne, dane udostępniane przez GUS, Bank Danych Regionalnych, zasoby Internetu. Posłużono się zatem tzw. triangulacją. Jest to strategia rozwiązywania problemów badawczych, polegająca m.in. na łączeniu kilku metod badawczych i służąca podniesieniu trafności badań ${ }^{22}$. Łącznie przeprowadzono 66 wywiadów. Za zgodą rozmówców nagrywano je dyktafonem. Łączny czas trwania wszystkich wywiadów wynosił w przybliżeniu 90 godzin; przeciętny wywiad trwał około 1,5 godziny.

Metoda analizy danych pochodzących z wywiadów polegała na kodowaniu tzw. transkrypcji, czyli spisanego tekstu wywiadu. W ramach pierwszego etapu analizy, dokonując transkrypcji, stworzono karty przypadków dla każdego $\mathrm{z}$ rozmówców ${ }^{23}$. W drugim etapie każda z kart poddano zakodowaniu z wykorzystaniem programu Atlas.ti v. $5 \cdot 0^{24}$. Przeprowadzone czynności pozwoliły zinterpretować wyniki.

\section{REZULTATY}

$\mathrm{Na}$ obszarze objętym badaniem funkcjonowało wiele różnych struktur partnerskich działajacych na rzecz rozwoju turystyki. Przedstawiono je w tabeli 2.

$\mathrm{Z}$ punktu widzenia celu artykułu na szersze omówienie zasługuje kilka z wymienionych w tabeli 2 organizacji partnerskich. W szczególności ważny dla dalszych rozważań jest rozwijany w latach 2005-2007 projekt o nazwie „Sieć turystyczna w Beskidach" ${ }^{25}$. Miał on na celu zintegrowanie działań sektora

22 J. Mason, Qualitative Researching, Sage, London 1996.

${ }^{23}$ M. B. Miles, A. M. Huberman, op. cit., s. 61.

${ }^{24}$ Zgromadzony materiał badawczy służący pierwotnym, szerszym badaniom, na podstawie których planowano zidentyfikowanie różnych grup uwarunkowań współpracy, ponownie zakodowano, tym razem, by osiagnąc cel artykułu.

${ }^{25}$ Projekt finansowany był ze środków Unii Europejskiej, Funduszu Społecznego i budżetu państwa w ramach Zintegrowanego Programu Operacyjnego Rozwoju Regionalnego. 


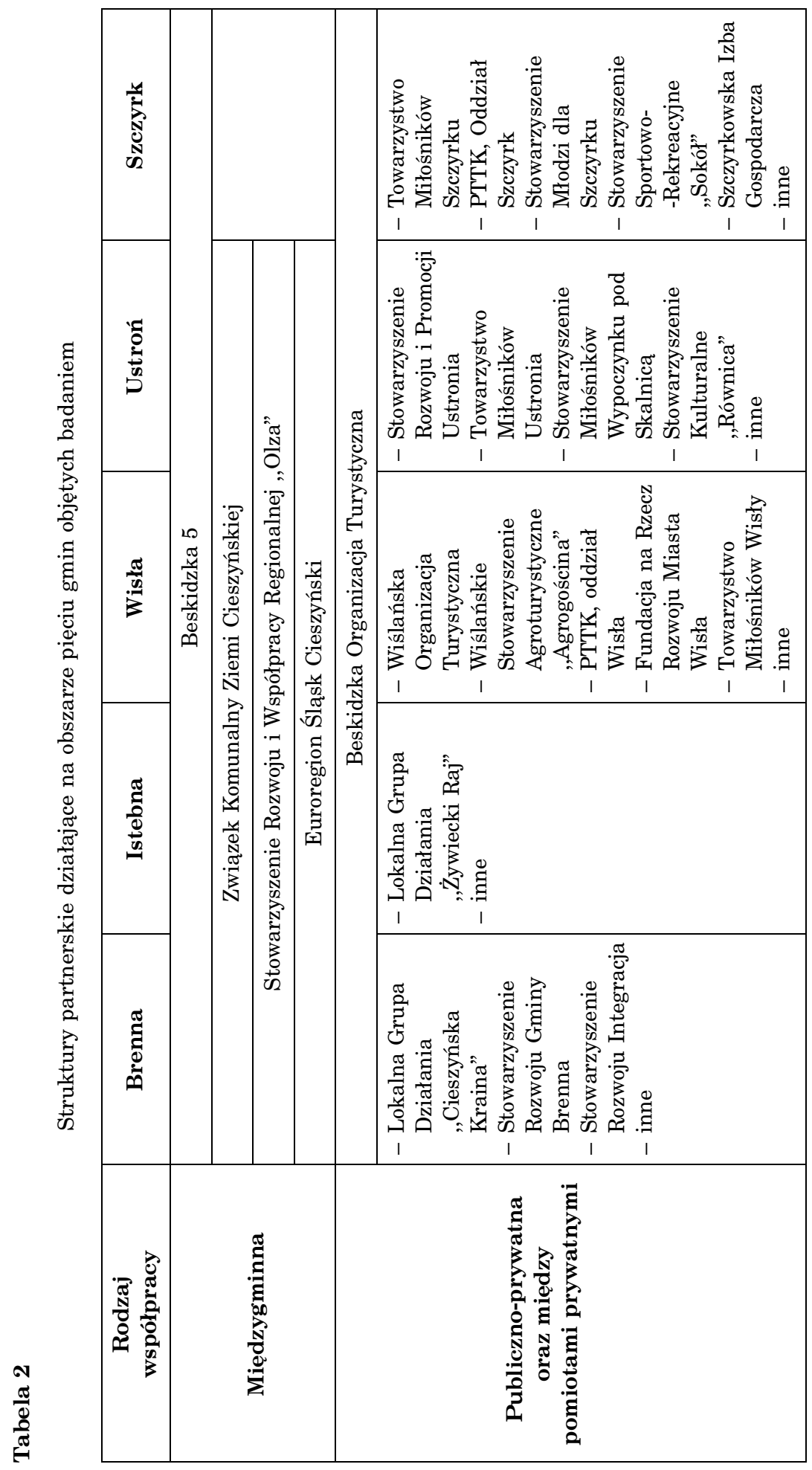

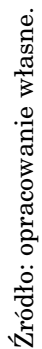


prywatnego i stworzenie na obszarze gmin „Beskidzkiej 5” klastra turystycznego, co miałoby służyć podniesieniu konkurencyjności tego obszaru. Efektem projektu było powołanie przez przedsiębiorców z obszaru pięciu gmin stowarzyszenia o nazwie: Beskidzka Organizacja Turystyczna (BOT). Ponieważ wiele działań w zakresie obu inicjatyw („Beskidzkiej 5” i BOT) było zbieżnych, przedstawiciele projektu ,Sieć turystyczna w Beskidach” zabiegali o to, by połączyć obie formy współpracy. Chcieli, by władze pięciu gmin przystąiłiły do BOT, która działałaby jako lokalna organizacja turystyczna i zrzeszała na równych prawach podmioty obu sektorów. Jednakże władze gminne odmówiły połączenia obu inicjatyw, do czego szerzej odniesiono się $\mathrm{w}$ dalszych rozważaniach.

Oprócz „Beskidzkiej 5” i Beskidzkiej Organizacji Turystycznej, które swym zasięgiem obejmowały podmioty ze wszystkich pięciu samorządów gminnych, każdy z nich lub podmioty z terenu danej gminy należały także do odrębnych organizacji partnerskich. W Wiśle działała m.in. Wiślańska Organizacja Turystyczna (WOT), zajmująca się rozwojem turystyki na terenie miasta (promowaniem Wisły przez organizację imprez, wydawaniem materiałów promocyjnych, udziałem w imprezach targowych itp.). Do WOT należał również samorzą gminny. Z kolei w Szczyrku istniała m.in. Szczyrkowska Izba Gospodarcza (SIG); zrzeszała przedsiębiorstwa, głównie prowadzące działalność związaną z turystyką, i współpracowała $\mathrm{z}$ władzami samorządowymi (np. w zakresie wymiany informacji, organizacji szkoleń/warsztatów, przeprowadzania kategoryzacji obiektów noclegowych itp.). W Ustroniu funkcjonowało natomiast Stowarzyszenie Rozwoju i Promocji Ustronia, zajmujące się organizowaniem kilku imprez $\mathrm{w}$ roku (głównie rajdów rowerowych i zawodów sportowych). W Istebnej działała m.in. Lokalna Grupa Działania - „Żywiecki Raj”, której członkiem był samorząd gminny i która podejmowała działania m.in. w zakresie tworzenia nowych atrakcji turystycznych w gminie. Do LGD należało 11 gmin wiejskich $\mathrm{z}$ powiatu żywieckiego i cieszyńskiego, w tym Istebna - jako jedyna z gmin „Beskidzkiej 5”. W Brennej natomiast działało m.in. Stowarzyszenie Integracja, zrzeszające podmioty prywatne podejmujące aktywność służącą rozwojowi społeczno-gospodarczemu gminy (m.in. poprzez rozwój turystyki). Funkcjonowała tam także Lokalna Grupa Działania „Cieszyńska Kraina”. Organizacja obejmowała 8 gmin wiejskich, w tym Brenną. Pozostałe gminy „Beskidzkiej 5” z powiatu cieszyńskiego do niej jednak nie należały, głównie ze względu na fakt, iż nie stanowiły gmin wiejskich. Istebna, która jako jedyna spełniała ten warunek, była członkiem wspomnianej wcześniej LGD ,Ż̇ywiecki Raj”. Ponadto wszystkie gminy, z wyjątkiem Szczyrku, należały do Stowarzyszenia Rozwoju i Współpracy Regionalnej „Olza” ${ }^{\prime 26}$, powstałego w efekcie utworzenia Euroregionu Sląsk Cieszyński. Miasto Szczyrk, jako jedyna gmina powiatu bielskiego, było członkiem Euroregionu Beskidy, zrzeszającego gminy pogranicza polsko-słowacko-czeskiego.

W efekcie przeprowadzonych badań stwierdzono przede wszystkim, że na obszarze pięciu gmin działania podejmowane przez różne organizacje partnerskie najczęściej nie były ze sobą skoordynowane, wiedza i doświadczenie zaś

${ }^{26}$ W dalszych rozważaniach używana będzie skrócona nazwa: Stowarzyszenie „Olza”. 
dotyczące celów, zadań i podziału ról między tymi strukturami były niewystarczające. Podmioty, zwłaszcza prywatne, miały ograniczona wiedzę na temat różnego rodzaju organizacji partnerskich, które moga podejmować działania na rzecz rozwoju turystyki. Przykładowo, niektórzy przedsiębiorcy ze Szczyrku nie rozumieli potrzeby tworzenia BOT, skoro funkcjonowały już SIG oraz „Beskidzka 5”, mimo że każda z organizacji miała inne możliwości i cele działania (pierwsza mogła zrzeszać na równych prawach sektor publiczny i prywatny, druga stanowiła platformę współpracy jedynie przedsiębiorców). Podobnie wielu rozmówców nie dostrzegało potrzeby tworzenia BOT, skoro ich zdaniem funkcjonowały gminne i powiatowe komórki (np. wydziały promocji), zajmujące się promocją turystyki na tym terenie. Przedsiębiorcy niewiele wiedzieli na temat partnerstwa publiczno-prywatnego (PPP), lokalnych grup działania czy innych rodzajów grup partnerskich. Twierdzono, że gdyby nie warsztaty i szkolenia organizowane w ramach projektu „Sieć turystyczna w Beskidach", wiedza na temat LOT/ROT także byłaby niewielka. Nie dostrzegano też niektórych możliwości kooperacji w formie określonych struktur partnerskich - np. często nie zdawano sobie sprawy, że można wspólnie, w ramach lokalnej organizacji turystycznej starać się o środki z budżetu UE.

Z kolei niektórzy przedstawiciele gminnych komórek organizacyjnych zajmujących się turystyką przedstawiali projekt „,Sieć turystyczna w Beskidach" jako konkurencyjny, a nie komplementarny w stosunku do inicjatywy „Beskidzka 5”. Urzędnicy nie wiedzieli ponadto, jak technicznie pogodzić funkcjonowanie obu inicjatyw. Twierdzili przykładowo, że w sytuacji gdy powstają takie organizacje, jak LOT, nie wiadomo, czy gmina powinna dofinansowywać udział tych organizacji np. w targach turystycznych, w których sama jako samorząd - uczestniczy, prezentując swoją ofertę. Dostrzegano w takich sytuacjach konflikt interesów.

Podobny problem sygnalizowano w kontekście jednoczesnej przynależności części gmin „Beskidzkiej 5” do Euroregionu Śląsk Cieszyński, a tym samym do Stowarzyszenia „Olza”, które koordynowało działania podejmowane w ramach euroregionu. Spośród pięciu gmin jedynie Szczyrk należał do Euroregionu Beskidy - odrębnej organizacji. W wypadku targów turystycznych pojawiał się dylemat, czy gminy powinny przedstawiać swoją ofertę jako „Beskidzka 5” czy też osobno - w ramach poszczególnych euroregionów. Rozmówcy podkreślali, że ich zdaniem, powodowało to problemy w jednoznacznym przekazywaniu turystom informacji dotyczących danego obszaru i jego specyfiki.

Jednoczesnemu funkcjonowaniu na tym samym obszarze wielu różnych struktur partnerskich towarzyszył także innego rodzaju problem. Początkowo, gdy opcja przystapienia gmin do BOT była jeszcze realna, nie potrafiono dokładnie stwierdzić, jak w stosunku do tej organizacji powinny funkcjonować dotychczasowe referaty/wydziały promocji poszczególnych gmin (podobnie było w Wiślańskiej Organizacji Turystycznej i tamtejszym referacie promocji). Część urzędników obawiała się utraty pracy, ponieważ uważała, że powołanie nowej organizacji zajmującej się promocją spowoduje, iż nie będzie potrzebne utrzymywanie etatów $\mathrm{w}$ wydziałach promocji $\mathrm{w}$ urzędach. Inni zaś pracownicy komórek organizacyjnych zajmujących się turystyką w gminach obawiali się , że 
w wypadku przystąpienia samorządów do BOT spadną na nich dodatkowe obowiązki.

Z kolei większość władz samorządowych z „Beskidzkiej 5” obawiała się przekazania Beskidzkiej Organizacji Turystycznej dodatkowych uprawnień i odpowiedzialności w zakresie promocji turystycznej, mimo że podmioty prywatne deklarowały chęć przejęcia części z tych obowiązków. W najmniejszym stopniu obawy tego rodzaju wyrażały władze Ustronia i Wisły. Burmistrzowie tych miast uważali, że wypracowane do tej pory przez „Beskidzką 5” rozwiązania $\mathrm{w}$ zakresie promocji gmin należałoby przekazać BOT. Obaj burmistrzowie uznawali, że w samorządach wiele rzeczy realizowanych jest tak, jakby urzędnicy uznawali, że mają na nie wyłączności, nie wierzyli, że przedsiębiorcy będą potrafili wykonać je tak samo, a nawet lepiej.

Jednym z przejawów braku skoordynowania działań partnerskich na obszarze objętym badaniem było prawie jednoczesne powstanie Wiślańskiej Organizacji Turystycznej, która zrzeszała przedsiębiorstwa z Wisły, i Beskidzkiej Organizacji Turystycznej, mającej skupiać podmioty z obszaru wszystkich pięciu gmin. Obie organizacje z założenia powstały w podobnym celu - wspierania, zwłaszcza poprzez promocję, rozwoju turystyki na danym terenie. Taka sytuacja rodziła ryzyko częściowego marnotrawienia potencjału współpracy i powielania tych samych wysiłków.

Brakowało też wiedzy, jak pogodzić funkcjonowanie na tym samym obszarze obydwu organizacji - czy mają się połączyć, czy działać oddzielnie. Ostatecznie Wiślańska Organizacja Turystyczna, która powstała nieco wcześniej pod naciskiem sektora prywatnego z terenu Wisły, została członkiem Beskidzkiej Organizacji Turystycznej. Rozmówcy mieli jednak poczucie, że organizacje zamiast współpracować konkurowały ze soba, przede wszystkim o pozyskiwanie nowych członków (to samo dotyczyło członkostwa Szczyrkowskiej Izby Gospodarczej w BOT). Jednocześnie członkostwo miasta Wisły w BOT rodziło problemy dotyczące płacenia składki - powstał konflikt o to, czy składkę powinna płacić WOT w imieniu swoich członków, czy też każdy z nich osobno. Drugie rozwiązanie byłoby korzystniejsze dla BOT, jednak spotkało się ze sprzeciwem członków WOT. Nie chcieli się oni bowiem godzić na płacenie składki członkowskiej w obydwu organizacjach. Ostatecznie doprowadziło to do rezygnacji podmiotów zrzeszonych $\mathrm{w}$ organizacji wiślańskiej $\mathrm{z}$ członkostwa w organizacji beskidzkiej.

Równocześnie podkreślano brak właściwego przepływu informacji między „Beskidzą 5” a BOT-WOT-SIG oraz fakt, iż wiele organizacji powstawało i szybko kończyło swoje funkcjonowanie bez żadnych efektów. To zniechęcało do współpracy i sprawiało, że wiele istniejących struktur partnerskich przedsiębiorcy postrzegali jako ,,sztuczne twory”, funkcjonujące głównie „,na papierze”.

Przynależność gmin do różnych struktur partnerskich sprawiała, że samorządy płaciły $w$ tych organizacjach składki członkowskie, chociaż miały świadomość, że przyjęte przez organizacje cele często nie są osiagane. Jednocześnie rozmówcy z sektora publicznego, podobnie jak z prywatnego, przyznawali, że między wieloma strukturami zrzeszającymi gminy i działającymi 


\section{Tabela 3}

Problemy wynikające z działalności wielu organizacji partnerskich na jednym obszarze

\begin{tabular}{|c|c|c|c|}
\hline Lp. & Rodzaj problemu & Przyczyna problemu & $\begin{array}{c}\text { Charakterystyka } \\
\text { problemu }\end{array}$ \\
\hline 1. & $\begin{array}{l}\text { Brak koordynacji } \\
\text { działań }\end{array}$ & $\begin{array}{l}\text { - brak lokalnego lidera } \\
\text { - dążenie reprezentantów } \\
\text { poszczególnych sektorów } \\
\text { (publicznego i prywat- } \\
\text { nego) głównie do włas- } \\
\text { nych celów, bez uwzględ- } \\
\text { nienia interesów pozo- } \\
\text { stałych podmiotów } \\
\text { - brak wiedzy, jak podzielić } \\
\text { role między sektorami, } \\
\text { jak rozwijać współpracę } \\
\text { w różnych jej formach } \\
\text { - brak doświadczeń w rów- } \\
\text { noprawnej współpracy } \\
\text { międzysektorowej }\end{array}$ & $\begin{array}{l}\text { - powielanie wysiłków } \\
\text { i brak efektywności } \\
\text { działania } \\
\text { - nieuzasadniona konku- } \\
\text { rencja, w tym konkuro- } \\
\text { wanie o członków orga- } \\
\text { nizacji } \\
\text { - problem członkostwa (kto } \\
\text { ma być członkiem i płacić } \\
\text { składkę - podmiot indywi- } \\
\text { dualny czy organizacja, } \\
\text { do której należy, będąca } \\
\text { również członkiem danej } \\
\text { struktury) } \\
\text { - powstawanie kolejnych or- } \\
\text { ganizacji, majacych zaspo- } \\
\text { kajać partykularne potrze- } \\
\text { by poszczególnych grup } \\
\text { - powstawanie organizacji } \\
\text { partnerskich kontrolowa- } \\
\text { nych przez wybrane pod- } \\
\text { mioty lub określony sektor } \\
\text { (brak równorzędności part- } \\
\text { nerów) }\end{array}$ \\
\hline 2. & $\begin{array}{l}\text { Niemożność pogodzenia } \\
\text { celów kilku organizacji } \\
\text { - sprzeczność interesów } \\
\text { różnych organizacji part- } \\
\text { nerskich }\end{array}$ & $\begin{array}{l}\text { - brak wiedzy na temat ce- } \\
\text { lów, do których powoływa- } \\
\text { ne sa określone organi- } \\
\text { zacje partnerskie } \\
\text { - brak wiedzy na temat ko- } \\
\text { rzyści funkcjonowania or- } \\
\text { ganizacji partnerskich } \\
\text { w różnych ich formach }\end{array}$ & $\begin{array}{l}\text { - konflikty w regionie i/lub } \\
\text { w poszczególnych gminach } \\
\text { tego regionu } \\
\text { - negatywne nastawienie do } \\
\text { powstawania kolejnych } \\
\text { form współpracy }\end{array}$ \\
\hline 3. & $\begin{array}{l}\text { Rozproszenie efektów dzia- } \\
\text { łania wielu organizacji } \\
\text { - postrzeganie ich jako } \\
\text { nieefektywnych (sztucz- } \\
\text { nych tworów) }\end{array}$ & $\begin{array}{l}\text { - obawy urzędników, że } \\
\text { z chwila powstania no- } \\
\text { wej struktury partnerskiej } \\
\text { będa musieli wykonywać } \\
\text { dodatkowa pracę lub stra- } \\
\text { ca pracę w urzędzie } \\
\text { - obawy urzędników, że stra- } \\
\text { cą część swojej władzy i ich } \\
\text { wpływ na rozwój gminy bę- } \\
\text { dzie mniejszy }\end{array}$ & $\begin{array}{c}\text { - działanie indywidualne } \\
\text { w sytuacji, gdy celowe } \\
\text { byłoby działanie wspólne }\end{array}$ \\
\hline 4. & $\begin{array}{l}\text { Techniczne problemy, jak } \\
\text { prowadzić działania pro- } \\
\text { mocyjne wielu różnych } \\
\text { organizacji partnerskich } \\
\text { danego regionu w czasie } \\
\text { jego promocji na zewnątrz }\end{array}$ & $\begin{array}{l}\text { - brak wiedzy i doświadcze- } \\
\text { nia w zakresie łączenia } \\
\text { działań promocyjnych róż- } \\
\text { nych organizacji partner- } \\
\text { skich, np. brak wiedzy, jak } \\
\text { podczas targów turystycz- } \\
\text { nych promować gminy, bę- } \\
\text { dące jednocześnie człon- } \\
\text { kiem wielu różnych struk- } \\
\text { tur partnerskich }\end{array}$ & $\begin{array}{l}\text { - marnotrawienie środków, } \\
\text { powielanie wysiłków } \\
\text { - przekazywanie turystom } \\
\text { niejasnych informacji } \\
\text { - konflikty między istnie- } \\
\text { jącymi strukturami part- } \\
\text { nerskimi }\end{array}$ \\
\hline
\end{tabular}

Źródło: opracowanie własne. 
na tym samym terenie brakuje współpracy. Przykładowo, urzędnicy twierdzili, że nie ma żadnej współpracy między Euroregionem Beskidy a Euroregionem Sląsk Cieszyński czy między „Beskidzką 5” a którąkolwiek z wymienionych struktur euroregionalnych.

Ostatnim zidentyfikowanym problemem było przekładanie się relacji międzygminnych (w ramach „Beskidzkiej 5”) na wewnętrzne relacje publiczno-prywatne w poszczególnych gminach. Burmistrzowie i wójtowie gmin podjęli bowiem decyzję, że do BOT przystąpią albo wszystkie samorządy gminne, albo żaden $\mathrm{z}$ nich. Wywiady z przedstawicielami poszczególnych gmin pozwoliły uznać, że zdania ich włodarzy były w tej kwestii podzielone. Gdy w efekcie nie doszło do przystąpienia samorządów gminnych do BOT, wywołało to niezadowolenie przedsiębiorców z poszczególnych gmin i przez krótki czas usztywniło relacje publiczno-prywatne między częścią przedsiębiorców a władzami/urzędnikami. Niezadowolenie sektora prywatnego z decyzji władz samorządowych dotyczyło zwłaszcza Brennej, a także kilku silnych przedsiębiorstw z Istebnej.

Podsumowując, przeprowadzone badania pozwoliły zidentyfikować i scharakteryzować cztery grupy problemów, które moga wynikać z funkcjonowania na jednym obszarze wielu organizacji partnerskich. Wskazano także na przyczyny występowania tych problemów (por. tabela 3).

\section{ZAKOŃCZENIE}

Badania pozwoliły zidentyfikować i scharakteryzować problemy związane z funkcjonowaniem na danym obszarze różnych organizacji partnerskich. Podjęto także próbę wskazania przyczyn zaistniałych problemów. W następstwie badań sformułowano dwie grupy konkluzji. Pierwsza ma charakter praktycznych wniosków płynących z badań. Druga grupa, zgodnie z charakterem badań eksploracyjnych, dotyczy sugestii co do kierunków dalszych badań empirycznych nad podjętą problematyką.

Badania pokazały, że $\mathrm{z}$ funkcjonowaniem na jednym obszarze wielu organizacji partnerskich może się wiązać wiele problemów. W szczególności utrudniona jest koordynacja działań podejmowanych w ramach tych organizacji. W takim wypadku następuje bowiem m.in. powielanie wysiłków, nieuzasadniona konkurencja między organizacjami, która nie sprzyja ich efektywnemu działaniu. Pojawiają się także problemy techniczne, jak pogodzić cele wielu struktur, a także ich zadania, np. z zakresu promocji. Badania pokazały, że działania różnych organizacji, których efekty są rozproszone i nie sa jednoznacznie widoczne dla ich członków, a także reszty społeczności, są postrzegane jako zbędne, stąd organizacje partnerskie nierzadko uznawane są za ,,sztuczne twory”, działające nieefektywnie. Powoduje to niechęć do tworzenia kolejnych struktur partnerskich, w tym takich, których powołanie byłoby w pełni uzasadnione.

Jako główną przyczynę tych problemów należy wskazać przede wszystkim brak odpowiednich kompetencji (wiedzy i doświadczenia) ze strony władz samorządowych, a także podmiotów sektora prywatnego, w szczególności:

- brak wiedzy i doświadczenia władz i urzędników samorządowych, jak pogodzić funkcjonowanie kilku struktur, w tym jak technicznie pogodzić pracę 
komórek organizacyjnych w urzędzie gminy zajmujących się turystyką z nowo powstałymi organizacjami, np. LOT,

- obawy urzędników, że w efekcie powstania nowej struktury partnerskiej spadną na nich nowe obowiązki lub będą bezużyteczni i stracą dotychczasową posadę $\mathrm{w}$ urzędzie,

- obawy władz samorządowych przed przekazywaniem części zadań samorządu gminnego podmiotom prywatnym,

- niewystarczająca wiedzę na temat potencjalnych struktur partnerskich w turystyce - brak znajomości specyfiki ich funkcjonowania, celów, zadań i korzyści z nich wynikających.

Zasadne wydaje się zatem organizowanie ciągłych szkoleń i warsztatów mających na celu zdobywanie wiedzy przez podmioty obu sektorów. W trakcie takich szkoleń potrzebne jest także prezentowanie pozytywnych przykładów kooperacji. Przełoży się to także na umiejętność skoordynowania działań między różnymi organizacjami, za co odpowiedzialne są w szczególności władze samorządowe jako podmiot predestynowany do pełnienia funkcji przywódczych na danym obszarze. Zasadne jest także zainwestowanie czasu i zasobów finansowych w spotkania struktur partnerskich działających na tym samym terenie lub w bliskim sąsiedztwie, by ustalić, jakie są cele i założenia funkcjonowania poszczególnych organizacji. Może się bowiem okazać, że wiele zadań można zrealizować wspólnie, co pozwoli obniżyć koszty i przez to działać bardziej efektywnie. Jednocześnie możliwe jest, że niektóre zadania można byłoby wdrażać na szerszą skalę.

Odnosząc się do drugiej grupy konkluzji - w postaci kierunków przyszłych badań - ponieważ miały one charakter eksploracyjny, ich celem było m.in. wyodrębnienie koncepcji i teorii badawczych użytecznych do dalszego zgłębiania poruszonej problematyki. Zdaniem autorki przydatne może być w szczególności wykorzystanie koncepcji transferu i absorpcji wiedzy na obszarze turystycznym (to właśnie jej brak był przyczyną zidentyfikowanych problemów). Użyteczna może być także teoria kooperencji (inaczej koopetycji), czyli jednoczesnej współpracy i konkurencji, która pozwoliłaby wyznaczyć i uzasadnić obszary współpracy i rywalizacji między istniejącymi na danym obszarze organizacjami partnerskimi. Jednocześnie specyfika podejmowanego zagadnienia, ściśle związanego $\mathrm{z}$ aspektami przestrzennymi i relacjami $\mathrm{w}$ tej przestrzeni, czyni użyteczną teorię sieci społecznych (SNA) i jej zarówno jakościowe, jak i ilościowe narzędzia analizy. Pozwoliłoby to np. zbadać gęstość relacji między strukturami, a także ich członkami oraz warunki dyfuzji wiedzy w sieci obszaru turystycznego. Lista wymienionych koncepcji teoretycznych, podobnie zresztą jak lista zidentyfikowanych problemów z pewnością nie jest ostateczna ze względu na złożony charakter badanego zagadnienia. Brak szerszych badań w tym zakresie składnia do dalszych analiz tej problematyki. Winny być one wielostronne i opierać się na wykorzystaniu różnych perspektyw badawczych.

dr Katarzyna Czernek

Uniwersytet Ekonomiczny w Katowicach

katarzyna.czernek@ue.katowice.pl 


\section{PARTNERSHIP ORGANISATIONS OPERATING IN THE SAME \\ TOURIST DESTINATION - PROBLEMS AND CHALLENGES}

\section{Summary}

The number of partnership structures in tourism (such as destination marketing organisations; tourist unions, tourist agreements, local activity groups) has been recently rising in Poland. Their establishment is often chaotic and not coordinated with other partnership organisations operating in the area. As a result, activities undertaken in cooperation by these organisations are not always effective and efficient as they are often double efforts and lead to unjustified competition. In the paper problems that frequently arise when different tourist organisations operate in the same area have been presented and an attempt has been made to identify the reasons for that. 
Copyright of Journal of Law, Economics and Sociology is the property of Faculty of Law and Administration of Adam Mickiewicz University in Poznan and its content may not be copied or emailed to multiple sites or posted to a listserv without the copyright holder's express written permission. However, users may print, download, or email articles for individual use.

Właścicielem praw autorskich do „Ruchu Prawniczego, Ekonomicznego i Socjologicznego” jest Wydział Prawa i Administracji Uniwersytetu im. Adama Mickiewicza w Poznaniu. Zawartość czasopisma nie może być kopiowana, przesyłana do innych stron internetowych bądź zamieszczana na blogach bez pisemnej zgody wydawcy. Niemniej artykuły można drukować, kopiować lub przesyłać w formie elektronicznej na własny użytek. 